Note

\title{
CAN A CALIFORNIA LITIGANT PREVAIL IN AN ACTION FOR LEGAL MALPRACTICE BA SE D ON AN ATTORNEY'S ORAL ARGUMENT BEFORE THE UNITED STATES SU PREME COURT?
}

\begin{abstract}
KRISTA M.ENNS
I have eaten the plums that were in the icebox and which you were probably saving for breakfast. Forgive me they were delicious so sweet and so cold. ${ }^{1}$
\end{abstract}

\section{INTRODUCTION}

O ne can only hope that this poem allowed a potential dispute over plums to be settled more peacefully than the dispute over plums that gave rise to a legal malpractice suit now pending in a California trial court. The lawsuit Campagne \& A ssocs. v. Gerawan Farming, Inc. ${ }^{2}$ stems from the oral argument presented to the Supreme Court in G lickman v. Wileman B ros. \& Elliott (Wileman). ${ }^{3}$ W ileman B rothers and E lliott, Inc. (Wileman), filed suit in 1988, challenging the constitutionality of the A gricultural M arketing A greement A ct of 1937 (A M A A ). ${ }^{4}$ A n A dministrative L aw J udge for the D epartment of A griculture held for Wileman, ${ }^{5}$ but was reversed by a USD A Judicial Officer. ${ }^{6}$ Subsequently, fifteen other litigants, including Gerawan

1. William Carlos Williams, This Is Just to Say, in 1 The Collected Poems of WILLIA M CA RLOS WILLIA M S 372, 372 (A . W alton Litz \& Christopher M acG owan eds., 1986).

2. No. 587667-7 (Cal. Super. Ct. filed A pr. 25, 1997).

3. 117 S. Ct. 2130 (1997).

4. 50 Stat. $246,246-49$ (codified as amended in scattered sections of 7 U .S.C.); see Wileman B ros. \& Elliot, 52 A gric. Dec. 5, 7-8 (E.D. Cal. 1993).

5. See Wileman B ros. \& Elliott, 50 A gric. D ec. 1165, 1171 (1991).

6. See Wileman, $52 \mathrm{~A}$ gric. D ec. at 41 n. 36 . 
Farming, Inc. (Gerawan), joined Wileman in the suit. ${ }^{7}$ The E astern District of California upheld the J udicial Officer's holding, but the Ninth Circuit reversed, holding the challenged provisions of the A M A A unconstitutional. In 1995, the Supreme Court granted certiorari to determine whether the provision of the $A$ ct that provides for mandatory assessments for generic advertising of California peaches, nectarines, and plums was constitutional. ${ }^{8}$

U ntil the Supreme Court agreed to hear the case, the lead attorney for W ileman et al., was Thomas A . Campagne, a generalist with a small practice in Fresno, California. ${ }^{9}$ A fter certiorari was granted, however, G erawan retained a separate attorney, M ichael W. M cConnell, a specialist in both First A mendment issues and oral argument before the Supreme Court. ${ }^{10}$ Gerawan insisted that Campagne step aside and let $\mathrm{M} c \mathrm{C}$ onnell write the brief for the respondents and present the oral argument to the Court. ${ }^{11} \mathrm{~N}$ otwithstanding strenuous pressure from thirteen of the sixteen respondents, Campagne refused G erawan's request ${ }^{12}$ and ultimately presented the oral argument himself. ${ }^{13}$ A fter the oral argument, the Supreme Court ruled against the respondents and upheld the constitutionality of the mandatory assessments for generic advertisements. ${ }^{14}$

7. See Wileman, 52 A gric. D ec. at 5 .

8. See G lickman v. Wileman Bros. \& Elliott, 517 U .S. 1232 (1996). Congress passed the A M A A to "establish and maintain ... orderly marketing conditions for agricultural commodities in interstate commerce." 7 U .S.C. § 602(1) (1994). The A ct covers various commodities, including California peaches, nectarines and plums. See 7 U.S.C. $\S \S 601,608$ (c)(6)(I) (1994). O ne program under the marketing order is the production of generic advertising to increase demand for the covered commodities. See 7 U .S.C. § 610(c)(6)(I) (1994). To pay for these programs, including the advertisements, handlers of the commodities covered by the A ct are assessed mandatory fees based on the volume of the commodity that each ships. See 7 U S.C. § 610(b)(2)(ii) (1994). G eneric advertising was extended to plums and nectarines in 1965, see A ct of N ov. 8, 1965, Pub. L. N o. 89-330, § 1(b), 79 Stat. 1270, 1270, and to peaches in 1971, see A ct of A ug. 13, 1971, Pub. L. N o. 92-120, 85 Stat. 340, 340.

9. See M artindale-H ubbell, M artindale-H ubbell L awyer L ocator (visited Nov. 16, 1998) $<$ http://lawyers.martindale.com/marhub/firm?_firm-no=749828001>.

10. See Letter from $D$ an G erawan, Gerawan Farming, Inc., to Thomas Campagne, Law Firm of Thomas Campagne \& A ssocs. 2-3 (A ug. 23, 1996) [hereinafter G erawan Letter I] (on file with Duke L aw J ournal).

11. See id. at 2 .

12. See Letter from Thomas Campagne, Law Firm of Thomas Campagne $\&$ A ssocs., to Chiamori Farms, Inc., Kobashi Farms, Inc., Tange Bros., Inc., Nagao Farms, Chosen Enterprises, Kobashi Farms, Nakayama Farms, Inc., and Mihara Farms 3 (Nov. 11, 1996) [hereinafter Campagne L etter] (on file with D uke L aw J ournal).

13. See J erry Bier, A llies in M arketing-O rder Case L ocked in D ispute, FRESNO BEE, J une 29,1997 , at B 1.

14. See G lickman v. Wileman B ros. \& E lliot, 117 S. Ct. 2130, 2142 (1997). 
D ebates about the benefits litigants receive from retaining specialists have been primarily academic. ${ }^{15} \mathrm{H}$ owever, the events underlying Wileman bring the discussion from the classroom to the courtroom. A fter the oral argument, G erawan filed a malpractice action in California state court against Campagne, ${ }^{16}$ alleging that Campagne's oral argument was deficient. ${ }^{17}$ Specifically, Gerawan posited that since Campagne had little previous First A mendment experience and no Supreme Court experience, Campagne had a duty to associate with-or at least consult —a Supreme Court specialist. ${ }^{18}$

Since Wileman was a Supreme Court decision, a legal malpractice claim creates an interesting possibility: to rule in Gerawan's favor, the trial court necessarily must hold that the Supreme Court should have decided Wileman differently. ${ }^{19}$ If the trial court comes to this conclusion, issues of res judicata and federalism appear to be implicated. ${ }^{20}$ However, to reach those issues, it must first be decided whether G erawan or similarly situated litigants can prevail.

This N ote uses Campagne to evaluate whether a litigant can recover for damages that allegedly occurred during oral argument before the Supreme Court. Part I of this Note identifies the terms "specialist" and "Supreme Court specialist" to provide background for Gerawan's charge. Part II sets the stage for Campagne, the malpractice suit filed by Gerawan. It begins by discussing the genesis of Wileman, its journey through the court system, and its resolution by the Supreme Court. The Part concludes with a review of the Campagne court's initial determination that failure to associate with, or

15. See 2 Ronald E. Mallen \& Jeffrey M. Smith, Legal Malpractice $\S 18.4$, at 559-60 (4th ed. 1996).

16. See M ark Thompson, $H$ ow to $G$ row $L$ awsuits: O ral A rguments $L$ and $L$ awyer B ack in Court, CA L. LA W., J an. 1998, at 23.

17. See First A mended Cross-Complaint at 11-12, Campagne \& A ssocs. v. Gerawan Farming, Inc., N o. 587667-7 (Cal. Super. Ct. filed J an. 14, 1998).

18. See id. at 14.

19. See 4 MALLEN \& SMITH, supra note 15 , § 32.1, at 128 .

20. If Gerawan prevails, it will have apparently bootstrapped an appeal of the U nited States Supreme Court via a legal malpractice action. When the Court denied the petitions to rehear Wileman, the First A mendment issue was resolved definitively. G iving G erawan relief, however, gives the appearance of allowing the trial court to review and reverse Wileman. At least one court, the Supreme Court of $U$ tah, has warned against using legal malpractice actions to bootstrap in other contexts. See H arline v. Barker, 912 P.2d 433, 440 (U tah 1996) ("We see no reason why a malpractice plaintiff should be able to bootstrap his way into having a lay jury decide the merits of the underlying 'suit within a suit' when, by statute or other rule of law, only an expert judge could have made the underlying decision."). 
professionally consult, a specialist can be the basis for a legal malpractice action.

In Part III, G erawan's charge is examined in the context of California's legal malpractice doctrine. In California, a legal malpractice action for negligence mirrors any other cause of action for negligence in that it has four elements: (1) duty; (2) breach (a negligent act or omission); (3) causation; and (4) damages. ${ }^{21}$ To prevail on a legal malpractice claim, the plaintiff must conduct what is termed a "trialwithin-a-trial." 22 That is, not only must the client prove that her attorney was negligent, the client must relitigate the underlying claim to prove that, but for the attorney's negligence, the outcome of the case would have been different. ${ }^{23} \mathrm{M}$ oreover, when a client alleges her attorney caused an adverse decision, the client must allege with specificity the particular issue(s) on which the attorney erred. ${ }^{24}$ Gerawan has identified four issues from Campagne's oral argument that a Supreme Court specialist would have argued differently. ${ }^{25}$ Part III evaluates Gerawan's chances of proving causation with respect to each of the four issues it has identified. It argues that although Gerawan can prove duty, breach, and damages, it will not be able to prove causation, and therefore will not prevail in its suit.

Part IV acknowledges the tension between the difficulty of proving causation in legal malpractice actions and one of the goals of legal malpractice, which is to allow litigants recovery when their attorneys are negligent. The part then considers the "loss of chance" doctrine, which is used in medical malpractice cases, as a possible alternative to the rigorous "but for" causation requirement in legal malpractice. Since a shift away from the "but for" standard is likely to cause more problems than it solves, and because adequate protections al ready exist for litigants, Part IV argues that the current causation requirements should be maintained for litigants who allege that they suffered an injury during Supreme Court oral argument.

\footnotetext{
21. See K urinij v. H anna \& M orton, 55 Cal. A pp. 4th 853, 863 (Ct. A pp. 1997).

22. See M attco Forge, Inc. v. A rthur Y oung $\&$ Co., 52 Cal. A pp. 4th 820, 832 (Ct. A pp. 1997).

23. See 4 M A LLEN \& SMITH, supra note 15 , § 32.1, at 128.

24. See 3 id. $\S 29.41$, at 772 ("In presenting the underlying appeal in the subsequent legal malpractice action, the parties must specify the issues that should have been urged in the underlying action.").

25. See infra pages 32-37.
} 


\section{The Origins of Specialization and the "Supreme Court SPECIALIST"}

To analyze a cause of action for "failure to associate with or professionally consult a specialist" in the context of Campagne v. Gerawan, the terms "specialist" and "Supreme Court specialist" must first be discussed. The emergence of specialization in Supreme Court practice followed the industry-wide movement in the legal profession toward specialization. ${ }^{26} \mathrm{~A}$ s early as 1910 , attorneys began to specialize in certain fields of law. ${ }^{27}$ B y 1950 , legal specialization had become so prevalent that members of the A merican Bar A ssociation (A BA) began debating whether to formally recognize specialties. ${ }^{28} O$ ver the next twenty years, the A BA created several committees to study the issue. ${ }^{29}$ In 1969, the A BA reserved judgment on the issue of a national plan of specialization pending results of experimental specialization programs at the state and local levels. ${ }^{30}$ Four years later, California became the first state to establish a specialty certification, and Texas followed shortly thereafter. ${ }^{31}$ Currently, twenty-one states formally recognize specialties. ${ }^{32} \mathrm{E}$ ven in the twenty-nine states where specialization is not formally recognized, it still exists. ${ }^{33}$

26. See generally $M$ ichael $A$ riens, $K$ now the $L$ aw: $A$ History of Legal Specialization, 45 S.C. L. REV. 1003, 1015-54 (1994) (discussing the history of specialization from 1870-1969); J udith Kilpatrick, Specialist Certification for L awyers: What Is G oing On?, 51 U. M IA MI L. REV . $273,275-90$ (1997) (describing various efforts to win recognition for specialization).

27. See A riens, supra note 26 , at $1027-28$ (citing corporate law as one of the first recognized fields of specialization).

28. See id. at 1042.

29. See id. at 1042-54. In 1953, the A B A created the Special Committee on Specialization and Specialized Legal Education to determine whether the ABA should create a permanent committee to regulate specialization. See id. at 1043. A Ithough the Special Committee recommended that the ABA do so, the recommendation was rejected in 1954. See id. In 1967, the Special Committee on A vailability of L egal Services concluded that "[r]ecognition and regulation of specialization in the practice of law [would] measurably improve the availability of legal services," id. at 1053, prompting the creation of another committee, the Special Committee on Specialization, see id. at 1053-54.

30. See id. at 1054.

31. See id. Each selected three fields for certification: California chose workmen's compensation, criminal law, and taxation; Texas opted for family law, criminal law, and labor law. See id.

32. See K ilpatrick, supra note 26 , at 289 ("A s of 1995, twenty-nine states still had no provision, active or inactive, for formal recognition of specialists.").

33. See A riens, supra note 26 , at 1005 ("It is the lawyer's expertise ... not the lawyer's degree in law or licensure by the state, that permits the lawyer to claim the mantle of professional."). A riens also argues that Peel v. A ttorney Registration \& D isciplinary Commission, 496 U.S. 91 (1990), effectively ended bar-controlled certification of specialists. See A riens, supra note 27 , at 1005 . The rationale behind this argument is that in Peel the Court held that a state 
O ne area in which attorneys have specialized, though the specialty has not received formal recognition, is the Supreme Court practice. The existence of Supreme Court specialists can be traced to the beginning of the nineteenth century. A that time, very few attorneys argued before the Supreme Court. ${ }^{34}$ Throughout the Marshall era (1801-1835), appearance before the Court was dominated by an elite group of attorneys. ${ }^{35} \mathrm{H}$ owever, there was a hiatus in such specialization until the latter part of the twentieth century. ${ }^{36} \mathrm{~A}$ fter the Civil War and through the twentieth century, this insular group was replaced by a "more fluid" set of attorneys. ${ }^{37}$ The fluidity became so pronounced that most attorneys who appeared before the Supreme Court were characterized as "once-in-a-lifetime lawyers." ${ }^{38}$ D uring the 1980s, however, practice before the Supreme Court began to be comprised, once again, of a select group. ${ }^{39}$

This latter group of attorneys who began to specialize in Supreme Court practice did so in response to three specific developments of the 1980s: (1) a change in the conduct of the Supreme Court Justices at oral argument, which demanded more diligent preparation; (2) statements made by Supreme Court J ustices outside of the courtroom which suggested that more experienced advocates were preferred; and (3) the proliferation of legal services in W ashington, D.C., which required law firms to distinguish themselves to remain competitive.

Changes in the Justices' conduct at oral argument began to be noticed in the middle of the 1980s. Prior to the 1980s, the Court was a much quieter place: "M ost of the justices were 75 years of age or older and quite content to listen to the arguments." ${ }^{40}$ A fter 1983, however, the J ustices became more active in their questioning of litigants. ${ }^{41}$ F or example, J ustices W hite, Stevens and $\mathrm{O}$ 'C onnor began to

may not prohibit non-misleading advertisement of an attorney's specialist certification by an unapproved certification board. See id. Since an approved certification board is no longer required, the bar can no longer monitor specialization.

34. See Kevin t. McGuire, The Supreme Court Bar: legal Elites in the WASHINGTON COMMUNITY 12 (1993).

35. See 3-4 G. Edward White, History of the Supreme Court of the United STA TES 202 (1988)

36. See MCGUIRE, supra note 34 , at 12 .

37. Id. at 21.

38. K athleen Sylvester, G earing U p to Sway the J ustices, NA T'L L.J ., J an. 24, 1983, at 1, 10.

39. See MCGUIRE, supra note 36 , at 21 .

40. D avid G. Savage, Say the Right Thing, 83 A .B .A . J ., Sept. 1997, at 54, 55.

41. See id. 
interject during oral arguments on a regular basis. ${ }^{42} \mathrm{~A}$ Ithough the actual date corresponding to the end of the "quiet" Court and start of the "hot" court is subject to debate, ${ }^{43}$ by the time Wileman was argued, participation by the J ustices during oral arguments was the rule rather than the exception. ${ }^{44}$ Consequently, oral arguments at the Supreme Court are no longer limited to recitations of prepared text. The Supreme Court J ustices are notorious for their complex hypotheticals, requests for concessions, and frequent questions. ${ }^{45}$

The second factor that sparked specialization was out-of-Court commentary by several of the Justices. This commentary indicated that the Court desired more experienced attorneys who prepared more thoroughly for oral argument. For instance, in a presentation at Georgetown U niversity in 1983, Chief Justice Warren Burger discussed the importance he placed on litigants having "experienced" and "qualified" attorneys conduct the oral argument. ${ }^{46}$ The same year, at Mercer U niversity Law School, then-A ssociate Justice R ehnquist emphasized the weight that the Supreme Court Justices place on oral arguments. He observed: "Oral advocacy is probably more important in the Supreme Court of the $U$ nited States than in most other appellate courts. ... . The opportunity to convince [the J ustices] of the merits of your position is at its highpoint." ${ }^{47}$ In addition to these explicit statements, some have found the Court's preference

\section{See id.}

43. Several commentators argue that 1986 is the watershed year for the change in the Court. See Bernard Schwartz, Decision: How the Supreme Court DeCides Cases 14 (1996); Savage, supra note 40, at 55. H owever, they disagree about the reason for the change. Compare SCHWARTZ, supra, at 14 (suggesting that the advent of the R ehnquist Court in 1986 was the precipitating factor for more active questioning), with Savage, supra note 40, at 55 (attributing the change to the fact that J ustice Scalia joined the Court in 1986).

44. See Savage, supra note 40, at 54. On today's Court, only J ustice Thomas consistently refrains from asking questions. See id. at 55.

45. See Stephen M. Shapiro, O ral A rgument in the Supreme Court of the U nited States, 33 CATH. U. L. REV . 529, 535 (1984) ("[N ]early every oral argument is punctuated with intense questioning, [and] the argument is not under counsel's complete control."); D avid Segal, Survival in the Lions' Den; Supreme Court Specialists Face Extraordinary Pressure for H uge Rewards. A nd B ruce Ennis Is on a Roll ..., WA SH. POST, A ug. 4, 1997, at F 12 (characterizing oral argument before the Court as a "free-for-all grilling"). This has led to attorneys referring to the $\mathrm{H}$ igh Court as a "hot" court. Sylvester, supra note 38, at 1.

46. Warren E. B urger, O pening R emarks at the Conference on Supreme Court A dvocacy (O ct. 17, 1983) (discussing efforts to improve the quality of advocacy before the Court and emphasizing that the Court does not favor divided arguments, reliance on prepared text during arguments, or longwinded arguments), in 33 CA TH. U . L. R E V . 525, 525-27 (1984).

47. William H. R ehnquist, Oral A dvocacy: A Disappearing A rt, B rainerd Currie M emorial Lecture (O ct. 20, 1983), in 35 MERCER L. REV. 1015, 1027-28 (1983-84). 
for experienced attorneys evinced in the R ules of the Supreme Court. For example, Professor D avid O 'Brien argues that the 1990 alteration of R ule 38 to read "[t]he Court looks with disfavor on any oral argument that is read from a prepared text," ${ }^{48}$ was a signal to both litigants and attorneys that the Court was frustrated with the quality of attorneys' oral advocacy. ${ }^{49}$

The proliferation of attorneys in W ashington, D .C., also contributed to the emergence of a Supreme Court specialty. B etween 1972 and 1983, membership in the Washington, D.C. bar more than tripled. ${ }^{50}$ To compete in the expanded legal market, firms in Washington, D.C., like firms across the nation, began to distinguish themselves by creating "specialty" practice groups, including Supreme Court specialty practice groups. ${ }^{51}$

Stephen M. Shapiro established the first modern Supreme Court specialty practice in 1983 at the D.C. office of the Chicago-based law firm of $M$ ayer, Platt and B rown ( $M$ ayer) ${ }^{52} \mathrm{~A}$ second firm introduced a Supreme Court practice shortly thereafter, ${ }^{53}$ and by 1997, twenty-

48. SUP. CT. R. 28 (1990) (amending SUP. CT. R. 38 (1980)). The current version of the rule states: "O ral argument read from prepared text is not favored." SU P. CT. R . 28 (1998).

49. See David M. O'Brien, Storm Center: The Supreme Court in American POLITICS 277-80 (4th ed. 1996).

50. Seejeffery M. Berry, The Interest Group Society 25 (1997),

51. See K ilpatrick, supra note 26 , at 285-87.

52. See A rthur S. H ayes, Supreme Court Specialty: D oes It Work?, A M. L A W., J une 1989, at 65, 65. A Ithough M ayer had a small Supreme Court practice in 1951, the practice began to expand significantly in 1983. See Steve France, Takeover Specialists: Why Many Litigators $\mathrm{H}$ and Their Cases to High Court Pros, 84 A.B.A . J., O ct. 1998, at 38, 39. Shapiro recalled that the idea for expanding the Supreme Court practice arose when he was the Deputy Solicitor $\mathrm{G}$ eneral in charge of business litigation from 1981-83. See id. While reviewing cases, he began to believe that "[t]here was a significant number of cases where clients weren't getting topnotch representation." Id. It is interesting to note that Shapiro was a presenter at the conference at which Chief J ustice Burger made his comments regarding unqualified attorneys appearing before the $\mathrm{H}$ igh Court. See Burger, supra note 46, at 525; Shapiro, supra note 45, at 529. A fter leaving the Solicitor G eneral's office, Shapiro began M ayer's Supreme Court practice in 1983. See Hayes, supra, at 65. To build the base of its Supreme Court practice, Mayer drew heavily on Solicitor G eneral alumni. In 1986, Shapiro persuaded three other veterans of the Solicitor G eneral's office to join him: D eputy Solicitor G eneral A ndrew L. Frey (a 14-year veteran), K enneth S. G eller, who oversaw civil litigation (a 10-year veteran) and Senior A ssistant Solicitor General Kathryn O berly (a 12-year veteran). See Talking Points; Top-L evel Turnover at Solicitor's O ffice, W A SH. Post, Mar. 7, 1986, at A 17. In 1989, M ayer added three other Solicitor General alumni: Michael McConnell, Roy Englert, and Michael Kellogg. See $\mathrm{H}$ ayes, supra, at 65 .

53. In 1985, Sidley and A ustin (Sidley), began its Supreme Court practice at its D.C. office. See M arcia Coyle, H igh Court B ar's “Inner Circle," N A T'L L.J., M ar. 3, 1997, at A 1. Carter G. Phillips, who clerked at the Supreme Court and served as an assistant to the Solicitor General, and former Solicitor G eneral R ex E . L ee started Sidley's practice. See id. 
two firms nationwide advertised a Supreme Court specialty ${ }^{54}$ Some of these firms have rather large teams of Supreme Court specialists ${ }^{55}$ and actively recruit attorneys for the teams. ${ }^{56}$

Based on cases that appeared before the Court from 1977 to 1982, Professor K evin M cG uire found data suggesting that lawyers with previous experience before the Court prevail "substantially more often." ${ }^{17}$ D ata from the Solicitor G eneral's office also support this theory. M embers of the Solicitor G eneral's legal team are, in essence, specialists- they only represent the $U$ nited States in appellate work before the Supreme Court and a few other federal courts. ${ }^{58}$ In the 1991-92 Term, the outcome in Supreme Court cases urged by these specialists prevailed more than 70 percent of the time. ${ }^{59}$

Thus, a litigant such as G erawan can make a strong case that de facto specialization has occurred throughout the legal profession, and that Supreme Court practice is an area in which such specialization exists. This, therefore, provides a foundation for Gerawan's allegation that failure to associate with or professionally consult a Supreme Court specialist is actionable legal malpractice.

54. See Segal, supra note 45 , at F 12 (citing M artindale-H ubbell).

55. For example, by 1989, Mayer's Supreme Court and A ppellate Litigation Practice Group had 21 attorneys, including 14 partners. See $\mathrm{H}$ ayes, supra note 52, at 65 .

56. A s illustrated by Mayer and Sidley, one source from which firms draw attorneys for a Supreme Court practice is the Solicitor G eneral's office. See supra notes 52-53 and accompanying text. A second source is former Supreme Court law clerks. In 1998, Sidley had about 20 former clerks working on its Supreme Court team. See France, supra note 52, at 38. In 1990, firms paid signing bonuses as high as $\$ 35,000$ to former clerks. See Eleanor K erlow, Supreme Court Payoff for Clerks: $\$ 35,000$ B onus; In Souring E conomy, Firms Sweeten P ot to L ure E lite Talent, LEGA L TIMES, Sept. 17, 1990, at 1. Firms also resort to other aggressive tactics to recruit clerks. For example, L atham and W atkins in L os A ngeles telephoned every clerk at the Court during the 1988-89 Term. See id. H owever, firms who choose to build their practice with former clerks face certain limitations. No former clerk can participate in any professional capacity in any case pending before the Court for two years. See SU P. CT. R . 7.

57. K evin M CG uire, Repeat Players in the Supreme Court: The R ole of Experienced L awyers in Litigation Success, $57 \mathrm{~J}$. POL. 187, 188 (1995) (finding that parties whose counsel had more experience with the Supreme Court than the opposing counsel had a higher probability of prevailing).

58. See 28 U .S.C. § 518(a) (1994) (stating that, unless the A ttorney G eneral directs otherwise, the Solicitor G eneral and A ttorney G eneral handle cases for the U nited States in the Supreme Court, the U nited States Court of A ppeals for the Federal Circuit, the U nited States Court of Federal Claims, and the Court of International Trade).

59. See J ohn G. R oberts J r., Riding the Coattails of the Solicitor General, LEGAL TIMES, Mar. 29, 1993, at 30. 


\section{ThE History OF CAMPAgNe V. GERA WAN}

Until recently, the debate over the merits of specialization has been predominantly academic. ${ }^{60} W$ hile courts have been careful not to endorse either side in the argument about specialization, ${ }^{61} \mathrm{Cam}$ pagne may force a judicial stance because $\mathrm{G}$ erawan alleges that association or professional consultation with a Supreme Court specialist should be mandatory, and that failure to associate with, or refer to, a specialist is actionable legal malpractice. ${ }^{62}$

Gerawan claims that if Campagne had associated with or consulted with a Supreme Court specialist for the oral argument in Wileman the position advocated by Gerawan and the other respondents would have prevailed. ${ }^{63}$

\section{A. G lickman v. Wileman Bros. \& Elliott: The U nderlying Case}

Gerawan's malpractice suit arose from a case heard before the Supreme Court during the 1996-97 Term. Wileman began in 1988 when Wileman Brothers \& Elliott, Inc. and K ash Inc. (K ash), producers of peaches, nectarines and plums in California's San J oaquin $\checkmark$ alley, filed a suit against the $U$ nited States D epartment of A griculture (USD A ), which challenged the A gricultural Marketind A greement Act of $1937^{64}$ on both constitutional ${ }^{65}$ and nonconstitutional ${ }^{66}$

60. Compare David R. Brink, Let's Take Specialization A part, 62 A.B.A. J. 191, 191 (1976) (arguing that even though specialists are compensated at a higher rate than generalists, clients derive an economic benefit from specialization because specialists can work more efficiently on complex issues within their fields and, therefore, bill fewer hours), and 0 . R andolph Rollins, The Coming of L egal Specialization, 19 U. RICH. L. REV. 479, 487 \& nn.32-33 (1985) (citing consumer-preference surveys from the 1970s and 1980s that indicate the public wants to hire specialists), with D emetrios D imitriou, The Individual Practitioner and Commercialism in the Profession: H ow Can the Individual Survive?, 45 S.C. L. REV. 965, 968-69 (1994) (arguing that "[a]s lawyers become more specialized, they tend to narrow their focus on the intricate and intellectually fascinating legal issues involved in the client matter," and that this myopia is ultimately detrimental to clients). See generally K enneth J. G oldsmith, Specialty-Certification A ccreditation, CRIM. J UST., Fall 1994, at 34, 34 (setting forth both sides of the argument).

61. See, e.g., M oran v. H arris, 131 Cal. A pp. 3d 913, 921-22 (Ct. A pp. 1982) (maintaining a neutral position, while acknowledging the argument that referral fees have the beneficial public policy effect of providing an incentive to less capable lawyers to seek out experienced specialists to handle a case).

62. See Decision Denying M otion to Strike at 14-15, Campagne \& A ssocs. v. Gerawan Farming, Inc., N o. 587667-7 (Cal. Super. Ct. decided N ov. 19, 1997).

63. See First A mended Cross-Complaint at 10-12, Campagne, No. 587667-7 (Cal. Super. Ct. filed J an. 14, 1998).

64. See Cindy Skrzycki, An A d Campaign Fight That's Ripe for the Picking, W A SH. PosT, Dec. 13, 1996, at D 1. 
grounds. In 1991, a USDA administrative law judge held for Wileman and $\mathrm{K}$ ash on the nonconstitutional challenges to the $\mathrm{A} \mathrm{ct}{ }^{67} \mathrm{Al}$ though the holding did not address the constitutional issues, ${ }^{68}$ the judge explained in dicta that W ileman and Kash would have prevailed had the First A mendment issues been reached. ${ }^{69}$ The government appealed, ${ }^{70}$ and in September 1991, a U SD A judicial officer reversed the holding on the nonconstitutional issues and explicitly held that the generic advertisement programs did not violate the First A mendment. ${ }^{71}$

A the time the judicial officer decided Wileman, Gerawan and other producers of peaches, plums and nectarines had pending claims with similar First A mendment issues. ${ }^{72}$ E ventually, their suits were consolidated with Wileman. ${ }^{73}$

65. Two constitutional grounds were alleged. First, the plaintiffs alleged a violation of the First A mendment. See W ileman B ros. \& Elliott, 52 A gric. D ec. 5, 41 (E.D. Cal. 1993) (alleging that the forced imposition of assessments for the purposes of generic advertising violated their First A mendment rights because it forced association with their competitors and it forced them to participate in a generic advertising program which was "contrary to their personal, professional, ideologic, philosophic and commercial beliefs"). Second, the plaintiffs alleged a violation of the Fifth A mendment. See id. at 46-47 (discussing allegations that plaintiffs were being discriminated against because "advertising assessments are imposed on handlers of California fruit, but not upon those who handle out-of-state or foreign fruit").

66. The producers alleged that the U SD A exceeded its authority when it promulgated the marketing orders. See id. at 7-8. H owever, since the Supreme Court only considered the generic advertising provisions, see G lickman v. W ileman Bros. \& Elliott., 117 S. Ct. 2130, 2134 (1996), discussion of this allegation is beyond the scope of this $N$ ote.

67. See Wileman B ros. \& Elliott, 50 A gric. D ec. 1165, 1171 (1991).

68. Since the $A$ dministrative $L$ aw J udge held for W ileman on the nonconstitutional claims, she disposed of the case without ever reaching the constitutional issues. See id. at 1217. sion).

69. See id. (noting that the discussion of this topic occupied 54 pages in the initial deci-

70. See id. at 1171.

71. See Wileman, $52 \mathrm{~A}$ gric. D ec. at 41 n.36.

72. See Gerawan Co., 50 A gric. Dec. 1363, 1364-65 (1991); A sakawa Farms, 50 A gric. Dec. 1144, 1147 (1991) (dismissing petitions of A sakawa Farms, Chiamori Farms, Phillips Farms, Kobashi Farms, Inc., Tange Bros., Inc., Nagao Farms, Nilmeier Farms, Chosen Enterprise, G eorge H uebert Farms, Wilmer H uebert Farms, K obashi Farms, Nakayama Farms, Inc., M ihara Farms).

73. See Wileman, $52 \mathrm{~A}$ gric. Dec. at 5. In addition to Gerawan Farms, Inc., the suit was joined by A sakawa Farms, Inc., Chiamori Farms, Inc., Chosen Enterprises, George Huebert Farms, K obashi Farms, Kobashi Farms, Inc., M ihara Farms, Nagao Farms, Nakayama Farms, Inc., Nilmeier Farms, Phillips, Inc., Tange Bros., Inc., and Wilmer H uebert Farms. See id; see also W ileman B ros. \& Elliot v. Espy, 58 F.3d 1367, 1374 (9th Cir. 1995) (noting consolidation of the parties' claims). 
In J anuary 1993, a federal district court affirmed the judicial officer's decision on all counts. ${ }^{74}$ Later that year, a three-judge panel of the $\mathrm{N}$ inth Circuit reversed the district court. ${ }^{75}$ It held that the generic advertising provisions for peaches, plums, and nectarines promulgated pursuant to the A MAA violated the First A mendment. ${ }^{76}$ The government petitioned for a rehearing en banc, which the Ninth $\mathrm{Cir}$ cuit denied. ${ }^{77} \mathrm{~A}$ fter the denial, the Solicitor $\mathrm{G}$ eneral was petitioned to support the position of the U SD A.$^{78}$ In mid-J anuary 1996, the Solicitor $\mathrm{G}$ eneral agreed to recommend the case to the Supreme Court. ${ }^{79}$ The Court granted certiorari on J une $3,1996 .{ }^{80}$

\section{B. Campagne v. Gerawan: The L egal M alpractice A ction}

A fter Wileman was granted certiorari, a significant disagreement developed between Campagne and one of the sixteen respondents, Gerawan. Gerawan retained Michael W. M cConnell, an attorney who had significant experience with First A mendment issues and who had previously argued before the Supreme Court. ${ }^{82}$ Through meetings and correspondence, Gerawan urged Campagne to refer to M cConnell as a resource. ${ }^{83}$ Subsequently, Gerawan shifted his position.

74. See Wileman, $52 \mathrm{~A}$ gric. $\mathrm{D}$ ec. at 5 .

75. See Wileman, 58 F.3d at 1380.

76. See id.

77. See id. at 1386; see also G eorge H ostetter, Court Backs G rowers on M arketing Program; A ppeal U pholds Decision on Generic Advertising, FRESNO BEE, Sept. 23, 1995, at A 1 (noting that the court rejected the $D$ epartment of $A$ griculture's request for a rehearing).

78. See Barbara D eL ollis, A g G roups H ead to High Court; M arketing Boards A sk the Solicitor General to Make Their Case B efore the Supreme Court, FRESNO BEE, O ct. 27, 1995, at C1. 19.

79. See Marni Katz, CTFA Case B ound for Supreme Court, Tree FruIt, Mar. 1996, at 19,

80. See G lickman v. Wileman B ros. \& E lliott, 517 U .S. 1232 (1996).

81. Professor M CConnell is the Presidential Professor at the $U$ niversity of $U$ tah College of Law, and his area of expertise is constitutional law. See Religious Liberty Protection Act of 1998: H earings on S. 2148 B efore the Senate Comm. on the Judiciary, 105th Cong. (J une 23, 1998) (statement of M ichael W. M cConnell, Professor, U niversity of U tah College of Law), available in LEXIS, N ews L ibrary, Curnws File.

82. See $\mathrm{G}$ erawan L etter I, supra note 10 , at 2 .

83. O ne example was a letter sent to Campagne in A ugust 1996. See id. The executive for Gerawan who wrote the letter stated that he "was advised by all three [consulting attorneys] that generally an attorney will advise his clients of the option of using a Supreme Court practitioner when a case reaches the Supreme Court." Id. The three consulting attorneys to whom Gerawan referred are McConnell, P. Cameron DeV ore (of Davis Wright Tremaine), and $D$ aniel E. Troy (of Wiley, R ein \& Fielding). See L etter from P. Cameron D eV ore, A ttorney, D avis W right Tremaine, to D an G erawan, Gerawan Farming, Inc. 2-3 (O ct. 24, 1996) (on file 
While Gerawan still hoped that McConnell and Campagne could collaborate on the merits brief, ${ }^{84} \mathrm{G}$ erawan began pressuring Campagne to defer to McConnell entirely for delivery of the oral argument. ${ }^{85}$ Campagne refused. ${ }^{86}$ R eportedly, when the deadline to submit the counsel-of-record forms to the Court arrived, Campagne and $\mathrm{McC}$ connell each indicated to the Court that they would present the oral argument for the respondents. ${ }^{87}$ When the Clerk of the Court called the respondents to clarify the situation, a bitter argument ensued between Campagne and McConnell. ${ }^{88}$ Since the respondents were unable to agree, the Clerk decided to determine who would deliver the argument by flipping a coin. ${ }^{89}$ Campagne emerged victorious and presented the oral argument. ${ }^{90}$

The day after Campagne's oral argument, McConnell wrote to the Clerk of the Court asking that a letter disavowing any concessions made by Campagne be circulated to the J ustices. ${ }^{91}$ R elations between Campagne and Gerawan continued to deteriorate after the oral argument. G erawan refused to pay Campagne for certain legal services and Campagne filed a lawsuit against Gerawan in California state court to recover his fees..$^{92}$ Gerawan then counterclaimed against Campagne for legal malpractice and various other torts. ${ }^{93}$ O ne of the eight causes of action Gerawan listed was a tort entitled "failure to

with Duke Law Journal); L etter from Daniel E. Troy, A ttorney, Wiley, Rein \& Fielding, to $D$ an $G$ erawan, G erawan Farming, Inc. 1 ( 0 ct. 22, 1996) (on file with D uke L aw J ournal). The executive added: "I $\mathrm{n}$ fact, each advised me that ... clients were usually better served by hiring a Supreme Court practitioner." G erawan L etter I, supra note 10, at 2.

84. See G erawan Letter I, supra note 10, at 6-7, 11 .

85. See id. at 10-11 (listing reasons why M cC onnell was better qualified to present the argument)

86. See Campagne Letter, supra note 12 , at 2. See also Letter from D an Gerawan, Gerawan Farming, Inc., to Thomas E. Campagne, L aw Firm of Thomas E. Campagne \& A ssocs. 1 (N ov. 4, 1996) [hereinafter G erawan L etter II] (on file with Duke L aw J ournal) (admitting the understanding that Elliott and $\mathrm{K}$ ash were leaving the decision of whether Campagne should consult $\mathrm{M}$ cConnell up to Campagne).

87. See Tony M auro, Clash of Cocounsel M ars Speech Case, LEGAL TIMES, Feb. 10, 1997, at 13 .

88. See id.

89. See id.

90. See id.

91. See Letter from Michael W. McConnell, Mayer, Brown and Platt, Counsel for Respondent Gerawan Farming, Inc., to William K. Suter, Clerk, Supreme Court of the U nited States 1 (D ec. 4, 1996) [hereinafter M cConnell L etter] (on file with D uke L aw J ournal).

92. See Thompson, supra note 16 , at 23 .

93. See Cross-Complaint at 37, Campagne \& A ssocs. v. Gerawan Farming, Inc., No. 587667-7 (Cal. Super. Ct. filed M ay 22, 1997). 
refer to specialist." ${ }^{94}$ A s support for this tort action, G erawan alleged that Campagne had a duty to defer to an attorney with more experience on First A mendment issues and more experience before the Supreme Court. ${ }^{95}$

Shortly after G erawan filed his counterclaim, the Supreme Court announced its decision in Wileman. In a 5-4 decision, the Court ruled against Gerawan and the other respondents. ${ }^{96}$ Campagne and Gerawan petitioned the Court for rehearing separately. ${ }^{97}$ The Court denied both petitions. ${ }^{98}$

W hile the denial of rehearing in Wileman terminated the underlying case, the controversy over whether Campagne committed legal malpractice during his oral argument is far from settled. In response to Campagne's procedural challenges to Gerawan's suit, ${ }^{99}$ the trial court judge reviewed the case and held that failure to defer to a specialist does not constitute an independent cause of action. ${ }^{100} \mathrm{H}$ owever, since Campagne had no previous Supreme Court experience, the judge held that Campagne may have had a duty to associate with or professionally consult another lawyer, ${ }^{101}$ and that the failure to meet this duty could support a legal malpractice cause of action for negligence. ${ }^{102}$

94. Id. at 34.

95. See id. at 34 .

96. See G lickman v. Wileman B ros. \& Elliott, 117 S. Ct. 2130, 2141-42 (1997).

97. See R espondents' Petition for R ehearing (Campagne), G lickman v. Wileman B ros. \& Elliott, 118 S. Ct. 25 (1997) (No. 95-1184) (petitioning on behalf of Wileman Bros. \& Elliott, Inc., K ash, Inc., G erawan Farming, Inc., A sakawa Farms, Inc., Chiamori Farms, Inc., Phillips Farms, Inc., K obashi Farms, inc., Tange B ros., Inc., Nagao Farms, Nilmeier Farms, Chosen Enterprises, G eorge H uebert Farms, Wilmer H uebert Farms, K obashi Farms, Nakayama Farms, Inc., and M ihara Farms); Respondents' Petition for Rehearing (Moody), Wileman (No. 951184) (petitioning on behalf of G erawan Farming, Inc., K ash, Inc.. Nakayama Farms, Inc., K obashi Farms, K obashi Farms, Inc., M ihara Farms, Nilmeier Farms, Chosen Enterprises, G eorge H uebert Farms, Tange Bros., Inc., Chiamori Farms, Inc. and Nagao Farms) Gerawan's new Counsel of R ecord was J ames A. M oody and B rian C. L eighton assisted in preparing the petition. See id. at 11.

98. See Wileman, $118 \mathrm{~S}$. Ct. at 25.

99. See D ecision D enying M otion to Strike at 14-15, Campagne, N o. 587667-7 (Cal. Super. Ct. decided Nov. 19, 1997) (ruling on Campagne's general and special demurrers to all eight causes of action for uncertainty and a motion to strike portions of the cross-complaint).

100. See id. at 14. Gerawan based his allegation on H orne v. Peckham, 97 Cal. A pp. 3d 404 (Ct. A pp. 1979), which held that failure to refer to a specialist in tax matters was negligence. See id. at 415-16. The trial court judge held that $\mathrm{H}$ orne was inapplicable to Campagne because it involved a "commonly recognized" legal specialty, tax, and Campagne did not. See D ecision D enying M otion to Strike at 14, Campagne, N o. 587667-7.

101. See D ecision D enying M otion to Strike at 14-15, Campagne, N 0. 587667-7.

102. Seeid. 


\section{Geraman Cannot Prevail in its Legal Malpractice Suit.}

To evaluate the merits of Gerawan's claim, it must be placed in the context of malpractice law. In California, a legal malpractice action for negligence is comprised of the same elements as other kinds of actionable negligence. ${ }^{103}$ Thus, for G erawan to succeed in its legal malpractice suit against Campagne, it must prove that Campagne owed it a duty, that Campagne breached that duty, and that the breach caused it to suffer damages. $E$ ven if $G$ erawan can prove that a duty existed, Campagne breached the duty, and that Gerawan suffered damages, it is unlikely that $\mathrm{G}$ erawan will be able to prove causation. Consequently, Gerawan cannot prevail in its malpractice action.

\section{A . Campagne's D uty to G erawan Farming}

If Gerawan is to be successful in proving legal malpractice, it must first establish that Campagne owed it a duty. ${ }^{104}$ There are at least two types of relationships that could give rise to a duty. The typical relationship that gives rise to a duty in a legal malpractice action is an attorney-client relationship. ${ }^{105}$ In Campagne, it is unclear whether such a relationship existed between Campagne and G erawan at the time of oral argument. In its complaint, Gerawan maintains that it was a client of Campagne's throughout the duration of Wileman, and that Campagne therefore owed it a duty. ${ }^{106}$ Campagne, on the other hand, avers that the attorney-client relationship terminated during the summer of 1996 when Gerawan retained M cConnell. ${ }^{107}$ Campagne reasons that Gerawan's "retention of successor counsel

103. See Nichols v. K eller, 15 Cal. A pp. 4th 1672, 1682 (Ct. A pp. 1993). The four elements are: (1) duty; (2) breach of that duty; (3) causation; and (4) damages. See id.; see also Lucas v. $\mathrm{H}$ amm, 364 P.2d 685, 686-87 (Cal. 1961) (discussing legal malpractice in terms of these four elements, but not explicitly setting them forth). A ccording to Mallen $\&$ Smith, "[t]he most common form of a legal malpractice action is for negligence." 1 M A LLEN \& SMITH, supra note $15, \S 8.1$, at 401 .

104. See Nichols, $15 \mathrm{Cal}$. A pp. 4th at 1682. The existence of a duty owed by the defendant to the plaintiff is a question of law for the court. See I shmael v. Millington, $241 \mathrm{Cal}$. A pp. $2 \mathrm{~d}$ 520, 525 (Ct. A pp. 1966).

105. See 1 MALLEN \& SMITH, supra note 15 , § 8.2, at 556 .

106. See Cross-Complaint at 6-7, Campagne, No. 587667-7 (Cal. Super. Ct. filed May 22, 1997); see also Gerawan L etter I, supra note 10, at 6-7 (stating that G erawan had not "left the group [of sixteen respondents]" and that it was "still a client" and "ha[s] been a client").

107. See G erawan L etter I, supra note 10, at 6 (recalling that Campagne informed G erawan that, as of A ugust 14, 1996, Campagne considered the relationship terminated). 
before the Supreme Court... vitiated any continuing duty of care [he] owed to G erawan Farming." ${ }^{108}$

Campagne's contention that Gerawan's retention of M cConnell abrogated the attorney-client relationship is supported by case law. Several courts have held that employing a second attorney severs the attorney-client relationship between the client and the first attorney. ${ }^{109} \mathrm{~A} n$ example is Belli v. Shaw. ${ }^{110}$ In B elli, the Washington Supreme Court held that "[e]mployment of other counsel, which is inconsistent with the continuance of the former relationship, shows an unmistakable purpose to sever the former relationship." ${ }^{111}$

Campagne was staunchly opposed to retaining $\mathrm{M} \mathrm{CC}$ onnell to assist in the preparation of the briefs and oral argument of Wileman. ${ }^{112}$ Prior to the oral argument, Campagne informed all the respondents who wanted $\mathrm{McC}$ connell to brief and argue Wileman that retaining McConnell was inconsistent with his [Campagne's] continuing to serve as their attorney. ${ }^{113}$ Consequently, Campagne informed them that retention of $\mathrm{McC}$ onnell terminated the attorney-client relationship with the respondents who stated a preference for M cConnell. ${ }^{114}$ Thus, the court could hold that the attorney-client relationship between Campagne and Gerawan was terminated by the time the alleged malpractice occurred and, therefore, that Campagne owed no duty to $\mathrm{G}$ erawan.

However, a second relationship that might give rise to a duty is an attorney-former client relationship. The prior existence of an attorney-client relationship forbids any act by the attorney that will injure the former client in matters involving that representation. ${ }^{115}$ The rationale behind this principle is "to remove any possibility of potential compromise ... due to divided or conflicting loyalties." ${ }^{116}$

E ven had the attorney-client relationship been abrogated, Gerawan's interests were still identical to those of the other respondents

108. Memorandum of Points and A uthorities in Support Thereof at 2, Campagne, No. 587667-7 (Cal. Super. Ct. filed J ul. 23, 1997).

109. See, e.g., Barry v. A shley A nderson, P.C., 718 F. Supp. 1492, 1494 (D. Colo. 1989); Belli v. Shaw, 657 P.2d 315, 319 (W ash. 1983).

110. 657 P.2d 315 (W ash. 1983).

111. Id. at 319.

112. See Campagne L etter, supra note 12 , at 1-3.

113. See id. at 1-2.

114. See id. at 2 .

115. See Y orn v. Superior Court, 90 Cal. A pp. 3d 669, 675 (Ct. A pp. 1979).

116. Id. 
in Wileman. Consequently, any action G erawan took with respect to Wileman would necessarily affect the matter in which he formerly represented Gerawan. Consequently, a trial court could, and likely would, find that Campagne had a duty not to take action that would injure his former client. Specifically, the trial court would find that Campagne owed Gerawan a duty because of the attorney-former client relationship.

Thus, whether the connection between Campagne and Gerawan was an attorney-client relationship or an attorney-former client relationship, the trial court could reasonably conclude that Campagne owed a duty to G erawan.

\section{B. Breach}

The existence of a duty would impose on Campagne the obligation to represent G erawan with the same care as "lawyers of ordinary skill and capacity commonly possess and exercise in the performance of the tasks which they undertake." ${ }^{117}$ The standard of care is that of members of the profession in "the same or similar locality under similar circumstances" ${ }^{118}$ and encompasses the obligation to make an "informed decision as to a course of conduct." ${ }^{119} \mathrm{G}$ eneral principles of fiduciary relationships and the California Model Rules of Professional Responsibility also govern the standard. ${ }^{120}$ If Gerawan can prove that the actions of Campagne did not meet this standard of care, it will have proven that Campagne breached the duty owed to Gerawan. ${ }^{121}$

To make the standard of care more concrete, the trial court will need to specify the appropriate comparison population under the "same or similar locality" requirement. ${ }^{122}$ In the context of medical

117. Lucas v. H amm, 364 P.2d 685, 689 (Cal. 1961); accord N eel v. Magana, O Iney, L evy, Cathcart \& G elfand, 491 P.2d 421, 423 (Cal. 1971) (citing the language used in L ucas); Crookall v. D avis, Punelli, K eathley \& W illard, 65 Cal. A pp. 4th 1048, 1067 (Ct. A pp. 1998) (same).

118. Smith v. L ewis, 530 P.2d 589, 592 n.3, 596 (Cal. 1975) (approving jury instructions containing the "same or similar locality under similar circumstances" language); accord U nigard Ins. Group v. O'Flaherty \& Belgum, 38 Cal. A pp. 4th 1229, 1237 (Ct. A pp. 1995) (citing the language used in L ewis); L ipscomb v. K rause, 87 Cal. A pp. 3d 970, 976 (Ct. A pp. 1978) (same); W right v. Williams, 47 Cal. A pp. 3d 802, 809 (Ct. A pp. 1975) (same).

119. L ewis, 530 P.2d at 595.

120. See M irabito v. Liccardo, 4 Cal. A pp. 4th 41 , 45 (Ct. A pp. 1992) ("[The] rules, together with statutes and general principles relating to other fiduciary relationships, all help define the duty component of the fiduciary duty which an attorney owes to his client.").

121. See id.

122. See L ewis, 530 P. $2 d$ at 592 n.3, 596 . 
malpractice, California courts have construed "locality" to mean "community." ${ }^{123}$ Since Campagne practices in Fresno, California, and Fresno is the largest metropolitan area in a 200 miles radius, the locality will probably be Fresno and the immediate area around the city.

In determining the standard of care, the trial court must also examine the specific situation in which Campagne found himself. ${ }^{225}$ Prior to Wileman, he had no prior Supreme Court experience or training in a Supreme Court practice. ${ }^{126}$ When reviewing Campagne's procedural challenges to $\mathrm{C}$ ampagne, the trial court judge determined that Campagne's lack of experience triggered the application of $\mathrm{R}$ ule 3-110(C) of the California M odel R ules of Professional R esponsibility, which states:

If a member does not have sufficient learning and skill when the legal service is undertaken, the member may nonetheless perform such services competently by 1) associating with or, where appropriate, professionally consulting another lawyer reasonably believed to be competent, or 2) by acquiring sufficient learning and skill before performance is required. ${ }^{127}$

Since R ule 3-110(C) governs, Campagne had an obligation to either associate with or professionally consult another attorney or acquire sufficient learning and skill prior to the oral argument. Further, legal malpractice doctrine mandates that Campagne make informed judgments with respect to the course of conduct taken. ${ }^{128} \mathrm{Combining}$ the analysis of the prior two paragraphs, in summary, the trial court

123. See Sinz v. O wens, 205 P.2d 3, 5-6 (Cal. 1949). In J effer, M angels \& B utler v. G lickman, 234 Cal. A pp. 3d 1432 (Ct. A pp. 1991), the California Court of A ppeals found "the law's treatment of medical malpractice is sufficiently analogous to legal malpractice for the standards regarding the qualifications of experts in medical malpractice cases to serve as a guide." See id. at 1438.

124. See M artindale-H ubbell, M artindale-H ubbell L awyer L ocator (visited Nov. 16, 1998) $<$ http://lawyers.martindale.com/marhub/firm?_firm-no=749828001>.

125. See I shmael v. M illington, 241 Cal. A pp. 2d 520, 526 (Ct. A pp. 1966).

126. See $L$ isa A grimonti, $L$ awyer $G$ ets $H$ is $D$ ay in Court, Santa Cla Ra MAg., Summer 1997, at 28 (stating that Wileman was Campagne's first Supreme Court argument). Campagne, however, was an experienced litigator, becoming a member of the California bar in 1975, see M artindale-H ubbell, M artindale-H ubbell Lawyer Locator (visited Nov. 16, 1998) $<$ http://lawyers.martindale.com/marhub/firm?_firm-no=749828001 $>$, and forming his own law firm in 1978, see A grimonti, supra, at 28 . The unique features of practice before the Supreme Court are explored at supra notes 26-59 and accompanying text.

127. Rules of Professional Conduct of the State bar of California Rule 3110(C) (1997).

128. See Smith v. L ewis, 530 P.2d 589, 596 (Cal. 1975). 
will consider whether a reasonable attorney from Fresno, California, in the position of Campagne, with no prior Supreme Court experience, would have made the decision to brief the Court and conduct oral argument himself.

In some circumstances, a trial court could recognize as reasonable the decision of a generalist to opt to acquire the skill and knowledge necessary to meet the standard of care envisioned by Rule 3$110(C)$. There is an obvious niche for Supreme Court specialists in the U nited States legal market, ${ }^{129}$ and California clients do not have many attorneys to chose from if they wish to have a California attorney brief and argue their case. ${ }^{130} \mathrm{M}$ oreover, attorneys rarely receive the opportunity to brief and argue before the Court ${ }^{131}$ and thus generalists who do not opt to take the opportunity to brief and argue the case when certiorari is granted are unlikely to receive other chances. R ecognizing the reasonableness of such a decision, therefore, will have a direct affect of increasing the number of attorneys with significant Supreme Court experience. This will expand the number of choices in the legal marketplace.

In Campagne's case, however, a court will probably determine that opting to acquire skill and knowledge was not reasonable. A s soon as Wileman was granted certiorari, Gerawan secured M cConnell's assistance for preparation of the brief and oral argument. ${ }^{132} \mathrm{Al}$ though cost often factors predominantly in the decision of whether to retain a specialist, ${ }^{133}$ G erawan removed cost from the evaluation by

129. See supra text accompanying notes 51-55.

130. Between 1977-82, only approximately six percent of the Supreme Court bar hailed from California. See M CG UIRE, supra note 36, at 131.

131. The Court only heard approximately 80 cases during the 1997-98 Term. See D avid Segal, F or D NC L awyers, Patience Is a N ecessary Virtue; Work? Plenty of It. High Profile? Sure. But $A$ bout the Check for L egal Fees... It M ight Be L ate., W A SH. POST, J an. 19, 1998, at F 9. It is true, however, that many law firms and advocacy groups file amicus briefs to boost their reputation as "Supreme Court savvy." A lexander Wohl, Friends with A gendas, 82 A .B.A . J., N ov. 1996, at 46, 48.

132. See D ennis Pollock, G rower-Packers Split on Choice of $L$ awyers; $A$ Case to Be A rgued B efore the U.S. Supreme Court on B ehalf of Valley Growers in D ecember $H$ as Two Candidates for Counsel, FRESNO BEE, Oct. 26, 1996, at C1 (stating that MCConnell was hired in early A ugust).

133. A ssociating with or consulting a specialist could create astronomical costs. Specialists earn $\$ 300-\$ 500$ per hour for their labors. See Segal, supra note 45 , at F 12 . E ven if firms do not bill hourly, the prices attached to Supreme Court advocacy still are incredibly high. For example, Sidley \& A ustin's Washington, D.C. office quoted the following figures for its Supreme Court practice: petitions for certiorari generally run $\$ 25,000-\$ 40,000$; amicus briefs at the certiorari stage run about $\$ 10,000$; briefs in opposition to certiorari, $\$ 5,000-\$ 10,000$; reply briefs, $\$ 5,000$; and oral arguments, $\$ 10,000-\$ 20,000$. See Coyle, supra note 53 , at A 1 . A necdotal evi- 
informing Campagne and the other respondents that he would pay all the bills for M cConnell's services. ${ }^{134} \mathrm{M}$ oreover, opposing counsel in Wileman was the Solicitor G eneral. The Solicitor G eneral is responsible for all cases before the Supreme Court in which the U nited States is a party, ${ }^{135}$ and consequently most attorneys in that office have vast amounts of experience and significant resources upon which to draw. Campagne, on the other hand, is the name partner in a small, eight-attorney law firm. ${ }^{136}$ Comparatively, it would seem that he did not have nearly as many resources or as much experience as his opponent.

The trial court should conclude that a reasonable generalist from Fresno with no prior Supreme Court experience would have associated with or professionally consulted a Supreme Court specialist, especially if a specialist was readily available, cost was removed from the equation, and the Solicitor $\mathrm{G}$ eneral was the opponent at oral argument. If the trial court so concludes, Gerawan will have proven breach.

\section{D amages ${ }^{137}$}

To prevail in its legal malpractice claim, Gerawan also must prove damages. "[D ]amages may not be based upon sheer speculation or surmise, and the mere possibility or even probability that damage will result from wrongful conduct does not render it actionable." ${ }^{138}$ The adverse decision in Wileman definitely had a financial impact on $\mathrm{G}$ erawan. $\mathrm{H}$ ad the Supreme Court decided Wileman in favor of the respondents, the $\$ 6.5$ million in marketing order assessments ${ }^{139}$ placed in trust would have been returned to the respondents. Since G erawan paid some of the money in the trust, ${ }^{140}$ when the ad-

dence suggests the estimate for oral argument is low. The sole practitioner from Wichita, $\mathrm{K}$ ansas, who argued O'Gilvie v. U nited States, 519 U.S. 79 (1996), stated that most Washington, D.C. firms that quoted a price for giving the oral argument cited a fee of $\$ 48,000-\$ 50,000$. See Coyle, supra note 53 , at A 1.

134. See G erawan L etter II, supra note 86 , at 2 .

135. See 28 U.S.C. § 518(a) (1994).

136. See M artindale-H ubbell, M artindale-H ubbell L awyer L ocator (visited N ov. 16, 1998) $<$ http://lawyers.martindale.com/marhub/firm?_firm-no=749828001>.

137. For ease of discussion, damages is discussed out of sequence.

138. In re E asterbrook, 200 Cal. A pp. 3d 1541, 1544 (Ct. A pp. 1988).

139. See Skrzycki, supra note 64 , at D 1 .

140. See First A mended Cross-Complaint at 12 , Campagne \& A ssocs. v. G erawan Farming, Inc., N o. 587667-7 (Cal. Super. Ct. filed J an. 14, 1998) (calculating that between 1989 and 1996, Gerawan Farming contributed $\$ 3,633,287$ pursuant to the marketing order). 
verse decision was entered, it lost its money. Therefore, if Gerawan satisfies the other three elements of legal malpractice, it will also meet the standard for damages: that it suffered "appreciable and actual harm." ${ }^{141}$

\section{Causation}

The presence of a duty, a breach, and damages is not sufficient for $\mathrm{G}$ erawan to succeed in its legal malpractice action. Causation also must be proven. ${ }^{142}$ That is, Gerawan must show a direct nexus between the breach and the damages. ${ }^{143} \mathrm{~A}$ direct nexus is shown if "but for" the attorney's breach of duty, the litigant would have received a favorable judgment from the court. ${ }^{144}$ Essentially, this requires the litigant to relitigate the underlying case in order to prove causation.

The relitigation of the underlying case is constrained by legal malpractice doctrine, which both requires the identification of a particular issue (or issues) that should have been argued differently ${ }^{145}$ and protects an attorney if reasonable interpretations of complex law $^{146}$ or reasonable tactical decisions are made. ${ }^{147}$ If an issue outside of the protected realm can be identified, it then must be shown that the attorney's position on the issue at oral argument caused the adverse decision. ${ }^{148}$ The elusive nature of the cause-in-fact requirement, in conjunction with the difficulty in identifying an issue that is not barred by protections given attorneys by legal malpractice doctrine makes causation difficult, if not impossible, to prove. ${ }^{149}$

1. G erawan $\mathrm{H}$ as Failed to I dentify an Issue that Falls $\mathrm{O}$ utside the A rea Protected by $L$ egal Malpractice $D$ octrine. Gerawan began its efforts to prove causation by identifying four issues in Campagne's

141. Thompson v. Halvonik, 36 Cal. A pp. 4th 657, 661 (Ct. A pp. 1995).

142. See U nited Community Church v. Garcin, 231 Cal. A pp. 3d 327, 334 (Ct. A pp. 1991); Lysick v. Walcom, 258 Cal. A pp. 2d 136, 153 (Ct. A pp. 1968).

143. See Sukoff v. Lemkin, 202 Cal. A pp. 3d 740, 744 (Ct. A pp. 1988).

144. See id.

145. See 3 MALLEN \& SMITH, supra note 15 , § 29.41, at 772 (“In presenting the underlying appeal in the subsequent legal malpractice action, the parties must specify the issues that should have been urged in the underlying action."). Failure to specify the issues is a failure to prove causation. See id.

146. See infra note 151 and accompanying text.

147. See Smith v. Lewis, 530 P.2d 589, 595 (Cal. 1975).

148. See Lysick v. Walcom, 258 Cal. A pp. $2 d$ 136, 153 (Ct. A pp. 1968). The attorney's action need not be the sole cause of the client's loss, just a substantial factor. See id. at 153 n.7.

149. See infra note 213 and accompanying text. 
argument that a specialist would have argued differently. These issues are: (1) whether the government has the authority under the First A mendment to decide who will speak for the growers or what messages will be communicated; (2) whether the generic advertising program would be constitutional if the advertising were confined to the homogenous products or common attributes of the products; (3) whether the constitutional violation could be cured by more specific findings by Congress or the Secretary of A griculture; and (4) whether the objections were primarily limited to maladministration of the program. $^{150}$

a. R easonable Interpretations of Complex P oints of $L$ aw are Protected. A $n$ analysis of the first three issues identified by Gerawan reveals that the differences between the arguments actually made by Campagne and the arguments Gerawan alleges a specialist would have made stem from differing interpretations of First A mendment law. A ttorneys are protected from malpractice liability if their interpretation of a complex legal issue "was clearly an arguable one upon which reasonable lawyers could differ." ${ }^{151}$ Thus, the trial court must first determine whether First A mendment law is sufficiently complex enough to trigger the protection and then evaluate whether the Campagne's position was reasonable.

The issues in Wileman implicated two lines of First A mendment doctrine. First, since the statutory provisions at issue dealt with commercial speech (advertising), the respondents argued that the generic advertising provisions could not pass the test set forth in Central Hudson Gas \& Electric Corp. v. Public Service Commission, ${ }^{152}$ the seminal case for commercial speech. ${ }^{153}$ Second, since the statutory

150. The day after the oral argument, M cC onnell sent a letter to the clerk of the Court. See M cConnell L etter, supra note 91 , at 1 . In this letter, he identified four issues from Campagne's oral argument with which $\mathrm{G}$ erawan did not agree. See id. Since M cC onnell is a specialist and he has already identified issues he would have argued differently, G erawan likely will rely on all issues listed in the letter.

151. L ewis, 530 P.2d at 594.

152. 447 U .S. 557 (1980). The Central H udson test has a four-part analysis: the speech must be protected by the First A mendment; the speech must concern a lawful activity and not be misleading; there must be a substantial government interest in restricting the speech; and the regulation must directly advance the government interest asserted and must not be more extensive than necessary to serve that interest. See id. at 566.

153. B rief for R espondents (M CConnell) at 13-32, Wileman (No. 95-1184) (arguing that the compelled advertising programs cannot be sustained under Central H udson); B rief for R espondents (Campagne) at*9-29, Wileman (N o. 95-1184) (same). 
provisions mandated financial contributions from the respondents, they argued that the challenged provisions could not survive the tests set forth for coerced speech. ${ }^{154} \mathrm{~B}$ oth lines of doctrine require intricate analysis. Moreover, two Circuits split over these issues. ${ }^{155}$ Consequently, a court probably will find the First A mendment doctrines at issue sufficiently complex to trigger the protection.

A $n$ analysis of each of the three issues illustrates that a court also probably will conclude that Campagne's positions with respect to the issues were reasonable. The first issue Gerawan identified was whether, under the First A mendment, the government has the authority to decide who will speak for the growers and what messages will be communicated. ${ }^{156}$ Campagne argued that the government sometimes, depending on the commodity, ${ }^{157}$ has the authority under the First A mendment to decide who will speak for the growers and what messages will be communicated. ${ }^{158}$ Specifically, he presented a narrowly focused argument: only the generic advertising provisions of the peach, nectarine, and plum marketing orders violated the First A mendment. ${ }^{159} \mathrm{G}$ erawan, on the other hand, alleges that a specialist would have taken a broader approach and argued the that any generic advertisements violate the $\mathrm{F}$ irst $\mathrm{A}$ mendment. ${ }^{160}$

When building his case, Campagne undoubtedly would have considered precedent in the area of generic advertising. A II previous lawsuits attacking the A M A A were targeted at the generic advertising provisions regarding individual commodities. ${ }^{161} \mathrm{~F}$ or example, in

154. See B rief for R espondents (M CConnell) at 33-41, Wileman (N o. 95-1184) (arguing that since the assessments are mandatory and the money pays for promulgating a message (advertisement), the marketing order is coercing speech in violation of the First A mendment); $B$ rief for R espondents (Campagne) at *42-49, Wileman ( $N$ o. 95-1184) (same).

155. See G lickman v. Wileman B ros. \& Elliott, 117 S. Ct. 2130, 2137 (1997) (stating that the petition for certiorari was granted to resolve the Circuit split).

156. See M cConnell L etter, supra note 91 , at 1.

157. See Transcript of O ral A rgument at 32, Glickman v. Wileman Bros. \& Elliott, $117 \mathrm{~S}$. Ct. 2130 (1997) (No. 95-1184) (stating that the respondents were not arguing that the generic beef and milk advertising programs were invalid).

158. See id. (responding "no" when asked whether all generic advertising programs are unconstitutional).

159. See id.; id. at 56 (stating that the respondents were not trying to "vitiate" the entire marketing order).

160. See Brief for R espondents (M cC onnell) at 10, Wileman (N o. 95-1184) (arguing that all government-sponsored collective advertising programs fail to satisfy the constitutional test used to evaluate interference with commercial speech).

161. See Cal-A Imond, Inc. v. U SD A, 14 F.3d 429, 432-33 (9th Cir. 1993) (challenging the generic advertising provisions of the A M A A for almonds); U nited States v. Frame, 885 F.2d $1119,1121-22$ (3d Cir. 1989) (challenging the generic advertising provisions of the A M A A for 
U nited States. v. Frame, ${ }_{1}^{162}$ a Third Circuit challenge to the constitutionality of the assessments for generic advertising imposed on the beef industry, ${ }^{163}$ the court's First A mendment analysis focused exclusively on beef. ${ }^{164}$ In Cal-A Imond, Inc. v. United States, ${ }^{165}$ almond producers challenged the generic advertising provisions of the marketing order solely in the context of almonds, ${ }^{196}$ and subsequently the Ninth Circuit's First A mendment analysis focused solely on almonds. ${ }^{167}$ Similarly, up until Wileman reached the Supreme Court, the focus was commondity-specfic and thus in reversing the district court's disposition of Wileman, the Ninth Circuit adopted a commodity-specific approach, focusing on peaches and nectarines. ${ }^{168} \mathrm{~A}$ lthough $\mathrm{G}$ erawan can make a case that a specialist would have made a broader argument, a court is likely to find that Campagne's approach was reasonable in light of the narrow approach taken by past litigants and courts.

The second issue, whether the program is constitutional if confined to homogenous products, ${ }^{169}$ is another permutation of the dispute between Campagne and Gerawan over how to construct the First A mendment argument. D uring oral argument, Campagne conceded that the program in question would be constitutional if applied to homogenous products. ${ }^{170} \mathrm{~A}$ gain, Campagne made a narrow argu-

beef). B etween 1991 and 1996, generic advertising by boards was challenged for at least nine individual commodities, including the boards for kiwis and apples. See K enneth $\mathrm{H}$ owe \& Julia A ngwin, Court Ruling Threatens A gricultural Ad Programs: Required Payments from Growers Could End, S.F. CHRON., M ay 31, 1996, at A 1.

162. 885 F.2d 1119 (3d Cir. 1989).

163. See id. at 1124-25.

164. See id. at 1129-37.

165. 14 F.3d 429 (9th Cir. 1993).

166. See id. at 433.

167. See id. at $433-40$.

168. See Wileman Bros. \& Elliott v. Espy, 58 F.3d 1367, 1380 (9th Cir. 1995). The Ninth Circuit did not consider the plum advertisement because the plum marketing order was terminated in 1991. See id. at 1373 n.1.

169. See M cConnell L etter, supra note 91 , at 1.

170. See Transcript of O ral A rgument at 43, G lickman v. Wileman B ros. \& Elliot, $117 \mathrm{~S}$. Ct. 2130 (1997) (N o. 95-1184). When attorneys refer to homogenous products, they are referring to commodities covered by the A M A A that they perceive as interchangeable such as milk. See id. at 35 (stating that “[w]hen you buy milk, you don't know if it's a jersey or a Guernsey milk you're drinking" and that since all milk is "white and wet... [there is not] much opportunity to prefer one [producer] over another"). Indeed, all dairy farmers bring their milk to a common processing plant where the milk is commingled, packaged, and sold. See The National Dairy Council, M ilking (visited Sept. 18, 1998) <http://www.milk.co.uk/milking.html>. Consequently, when advertising milk, the emphasis is on the product, not the particular brand. Like most tree 
ment that sometimes generic advertising provisions for agricultural commodities are constitutional. ${ }^{171} \mathrm{G}$ erawan contends that a specialist would not have made such a concession. R ather, G erawan posits that a specialist would have made a broad argument that the challenged program is unconstitutional whether applied to homogenous or nonhomogenous products. ${ }^{172}$

The difference of opinion between the two parties again hinges on Campagne's selection of a commodity-specific approach. Campagne attempted to distinguish the category to which peaches, plums and nectarines belong, the non-homogenous group, from the universe of homogenous products, such as milk; G erawan argues that any generic marketing provision instituted by the government is invalid. A court, therefore, again is likely to find that Campagne's position was reasonable and thus protected.

The third issue identified by Gerawan, whether or not specific findings by the Department of A griculture would impact the outcome of Wileman, ${ }^{173}$ is also a reasonable disagreement over a complex area of First A mendment law. D uring the oral argument, Campagne conceded that if the record contained findings by the Secretary of A griculture that the generic advertising program directly advanced the government's interest, then he would not contest the generic ad-

fruit, however, peaches, nectarines, and plums are distributed under a brand name. See Brief for R espondents (M CConnell) at 5, Wileman (No. 95-1184). There are numerous varieties of each commodity, see id. at $5 \mathrm{n} .5$ (stating that California produces at least 69 varieties of peaches, 61 varieties of plums, and 80 varieties of nectarines), and there are significant differences in taste and quality among different varieties, see id. at 6 . M oreover, agriculturists believe that different farming practices can result in distinct, higher quality production within the varieties. See id. at 18-19. In sum, agriculturists believe that peaches, nectarines and plums are nonhomogeneous commodities. The importance of whether a product is homogenous relates to economic theory. If products truly are fungible, producers would not benefit significantly from open competition because advertising would merely encourage a shift in the demand from one similar product to the next. See Jim Rossi \& Mollie Weighner, An Empirical Examination of the lowa Bar's A pproach to Regulating L awyer Advertising, 77 I OWA L. REV. 179, 227 (1991) (discussing, in the context of lawyer advertising, the economic theory that advertising of relatively homogenous products leads to price competition among sellers). E ach seller would have an incentive to reduce prices in an attempt to regain his or her share of the market. See id. Generic advertising for homogenous products enhances overall demand through consumer information. See Brief of A mici Curiae States of A rizona, California, Florida, M ichigan, N ebraska, $\mathrm{N}$ ew J ersey, N ew Y ork, O regon, V ermont, and V irginia, Wileman (No. 95-1184), available in 1996 W L 426255, at*20-22. With an overall increase in demand, producers will be able to raise prices. See id. Therefore, advertising can act as a price support. See id.

171. See Transcript of O ral A rgument at 43, Wileman (N 0. 95-1184).

172. See M cConnell L etter, supra note 91 , at 1.

173. Seeid. 
vertising provisions ${ }^{174} \mathrm{G}$ erawan, on the other hand, argues that such findings are irrelevant to the case because the entire marketing order cannot survive a constitutional challenge. ${ }^{175}$

Since Campagne's approach is based directly on the Ninth Circuit's decision in Wileman, ${ }^{176}$ the trial court is likely to conclude that Campagne's position was reasonable and therefore protected. As mentioned previously, advertisements fall under the rubric of commercial speech doctrine. ${ }^{177}$ Since the provision of the A M A A at issue in Wileman was generic advertisements, the courts reviewed whether the advertisements passed the Central Hudson test. ${ }^{178}$ The Ninth Circuit determined that the advertisements at issue were permitted under the First A mendment, ${ }_{1}^{179}$ were not misleading ${ }_{1}^{180}$ and served a substantial government interest. ${ }^{181}$ Therefore, it continued its analysis with a review of whether the regulation directly advanced the government's interest. Since the government could not prove the superiority of the generic advertising program to individual advertising, the court held that the generic advertising program did not directly advance the substantial interest the government had, and therefore failed the Central Hudson test. ${ }^{182}$ By taking the position he did, Campagne, in effect, was stating that had the government showed the advertisements directly advanced the government interest, the advertisements could have survived under Central Hudson. Since Campagne's approach to this issue is well-grounded in prior case law,

174. See Transcript of O ral A rgument at 45, Wileman (No. 95-1184) (emphasizing that if the government is going to require assessments for generic advertising, the government must "show a problem that requires a governmental compelling interest").

175. See Brief for Respondents (McConnell) at 16, Wileman (No. 95-1184) (arguing that agricultural marketing programs are "naked preferences" for politically favored industries).

176. See Wileman B ros. \& Elliott v. Espy, 58 F.3d 1367, 1378-79 (9th Cir. 1995).

177. See Central Hudson Gas \& Elec. Corp. v. Public Serv. Comm'n, 447 U .S. 557, 563 (1980).

178. See supra note 152 (setting out the four-part Central $\mathrm{H}$ udson test).

179. See Wileman, 58 F.3d at 1377-78.

180. See id. at 1378 (implying that the speech was non-misleading by stating that it would apply Central Hudson, the test for restrictions on "lawful, non-misleading commercial speech").

181. Seeid.

182. See id. at 1379. The Ninth Circuit conducted the following analysis: "whether the mandatory generic advertising program sells the product more effectively than the 'specific, targeted marketing efforts of individual handlers.'" Id. at 1378 (quoting Cal-A Imond, Inc. v. U SD A , 14 F.3d 429, 439 (9th Cir. 1993) (finding that generic advertising by the U SD A did not "directly advance" the government's interests in promoting almond sales under the Central $H$ udson test because the U SDA presented no evidence to indicate that its generic advertising was more effective than the advertising that the individual handlers would have done without the federal program)). 
the trial court is likely to conclude that his concession was reasonable and thus protected. Consequently, G erawan will not be able to build its case on any of the first three issues.

b. Reasonable Tactical Decisions Made by Attorneys A Iso A re Protected. The fourth issue, whether the objections were primarily limited to maladministration of the program, is also likely to be found protected because $C$ alifornia malpractice law protects reasonable tactical decisions made by attorneys. ${ }^{183}$

$W$ ith respect to the issue in question, Campagne could argue that he consciously constructed his argument to focus on the maladministration aspect of the program as a tactical decision. When Wileman was before the Ninth Circuit, that court held that any government program that burdens speech may not be sustained under Central Hudson if it "provides only ineffective or remote support for the government's purpose." ${ }^{184}$ Campagne's attempt to demonstrate that the advertising programs provided only ineffective or remote support for the government's interest in maintaining the stability of peach, nectarine and plum markets could be found to be a reasonable tactical decision by the trial court. Thus, the fourth issue, like the other three, is likely to be protected.

2. Even A ssuming Campagne's Position on O ne of the Four Issues Is N ot Protected, G erawan Will Fail to Prove Causation. Should the trial court conclude that one of these issues does not fall under the protections granted by legal malpractice doctrine, it would still remain for G erawan to prove that Campagne's oral argument was the cause-in-fact of the adverse decision by the Supreme Court. To prove that the oral argument was the cause-in-fact, Gerawan must show that Wileman should have been decided differently. ${ }^{185}$ In sum, Gerawan must persuade the trial court that given a different oral argument, a "reasonable" Supreme Court J ustice would have held the ge-

183. See Smith v. Lewis, 530 P.2d 589, 595 (Cal. 1975); see also K irsch v. D uryea, 578 P.2d 935, 939 (Cal. 1978) (recognizing that attorneys engaged in litigation should be granted latitude in choosing between alternative tactical strategies).

184. See Wileman, 58 F.3d at 1378 (quoting Central Hudson Gas \& Elec. Corp. v. Public Serv. Comm'n, 447 U .S. 557, 566 (1980)).

185. See M attco Forge, Inc. v. A rthur Y oung \& Co., 52 Cal. A pp. 4th 820,840 (Ct. A pp. 1997) (noting that "[i]t is the universal rule that the elements of causation and damages ... require the determination of what should have happened in the underlying case" (internal quotation marks omitted)). 
neric advertising provisions of the $\mathrm{AMAA}$ violated the First A mendment.

In order to show that a J ustice would have changed her mind if she had heard a different oral argument, G erawan must show that a reasonable Justice considers oral arguments important. A mple historical evidence exists that suggests that Supreme Court J ustices do not firmly decide cases prior to oral argument and that there are many vote switches between the time the J ustices read the case briefs and the time the opinion is issued. ${ }^{186} \mathrm{G}$ erawan can probably persuade the trial court that oral argument is important to the reasonable J ustice. The preponderance of statements made by judges and J ustices support the thesis that oral argument is important. ${ }^{187}$ E ven J ustice Scalia, who referred to oral arguments as a "dog and pony show" before his appointment to the Court, has come to regard oral argument as an important part of the appellate process. ${ }^{188}$ Consequently, Gerawan can probably establish the threshold for its effort to prove causation.

O nce it is established in principle that oral argument could have influenced the decision in a case before the Supreme Court, a causal relation between the particular oral argument and the adverse decision must be proven. ${ }^{189} \mathrm{~A}$ causal relationship may be assumed if "as a matter of ordinary experience, a particular act or omission might be expected to produce a particular result, and if that result has in fact followed." 190

To satisfy its burden of proof, Gerawan presumably will call witnesses to testify that, given Campagne's concession, the outcome in

186. See SCHWARTZ, supra note 43, at 178-206 (discussing how "vote switches have been a prominent feature of the decision process throughout the Supreme Court's history").

187. See Robert Stern et al., Supreme Court Practice: For Practice in the SUPREME COURT OF THE U NITED STA TES 569 (7th ed. 1993).

188. O'BRIEN, supra note 49, at 281 (claiming that Scalia's position with respect to oral argument has softened). Despite the fact that Gerawan can probably demonstrate that oral argument is important to Chief J ustice R ehnquist and J ustice Scalia, the emphasis several of the other J ustices place on oral argument is unknown. M oreover, J ustice Thomas reportedly bases no part of his decisions on oral argument, and decides cases solely on the briefs. See Savage, supra note 40, at 55-56. It appears, however, that J ustice Thomas's approach is the exception rather than the rule. See STE R N ET A L., supra note 187, at 569.

189. See $\mathrm{M}$ attco Forge, $52 \mathrm{Cal}$. A pp. 4th at $841-42$ (noting that it is not enough for a malpractice plaintiff to prove that the defendant's services were negligent and, therefore, could have caused unsuccessful disposition of the plaintiff's claim, but rather that the plaintiff must prove that the defendant's negligence did in fact cause the adverse decision).

190. Osborn v. Irwin Mem'l Blood Bank, 5 Cal. A pp. 4th 234, 253 (Ct. A pp. 1992) (emphasis added). 
Wileman was expected. O ne witness option that is precluded is asking the J ustices themselves to testify. N otwithstanding other issues involved with subpoenaing the J ustices, California case law states that testimony by a judge about matters that took place before her in her judicial capacity is too prejudicial. ${ }^{191}$ Thus, Gerawan must rely on other witnesses.

A Iready, two attorneys have sent memoranda to the California trial court opining that $C$ ampagne was the direct cause of the Court's decision. O ne of these attorneys is J ames A. M oody, a solo practitioner from W ashington, D.C. ${ }^{192}$ M oody submitted a declaration to the court averring that Campagne's oral argument was "defective" and was the "direct and proximate cause of the 5-4 reversal." ${ }^{193}$ The second is $\mathrm{P}$. Cameron $\mathrm{D}$ eV ore, an attorney at $\mathrm{D}$ avis $\mathrm{W}$ right Tremaine in Seattle, ${ }^{194}$ who stated: "In my judgment, the 5-to-4 loss that M r. Campagne and the respondents in [Wileman] suffered in that case in the U.S. Supreme Court was caused, in substantial part, by the unresponsive and unsophisticated oral argument made by Mr. Campagne to the Court in the case." ${ }^{195}$

The defense surely will point out to the trial court that both of these attorneys were affiliated with $\mathrm{G}$ erawan prior to the oral argument and that both advocated the retention of $\mathrm{McC}$ onnell to brief and argue the case. ${ }^{196}$ Thus, Campagne probably will be able to convince the trial court that the two witnesses were predisposed to favor

191. Merritt v. Reserve Ins. Co., 34 Cal. A pp. 3d 858, 883 (Ct. A pp. 1973) (stating that when a judge is an expert witness for matters that took place before her, it "appears [that she is] throwing the weight of [her] position and authority behind one of two opposing litigants" and that "it [is] only slightly less prejudicial when a judge expresses his opinion as a witness about events that occurred in an earlier trial over which he had presided").

192. Moody reportedly is "one of the leading experts on the history, law, administration, policy, and reform of agricultural marketing orders issued under the A gricultural Marketing A greement A ct of 1937." D eclaration of J ames A . M oody at 2, Campagne \& A ssocs. v. Gerawan Farming, Inc., N o. 587667-7 (Cal. Super. Ct. filed M ay 5, 1998).

193. Id. at 21. In addition, shortly after oral argument, M oody sent Campagne a letter in which he predicted that the Supreme Court would likely reverse the $N$ inth Circuit because of Campagne's faulty argument. See B ier, supra note 13, at B 1 .

194. See D eclaration of P. Cameron D eV ore at 1, Campagne, N 0. 587667-7 (Cal. Super. Ct. filed May 1, 1998). DeV ore's practice focuses on the First A mendment, and he has handled numerous First A mendment cases before the Supreme Court. See id.

195. Id.

196. See L etter from P. Cameron $D$ eV ore, D avis W right Tremaine, to D an Gerawan, Gerawan Farming, Inc. 2-3 (O ct. 24, 1996) (on file with the Duke Law Journal) (arguing that $\mathrm{McC}$ onnell, not Campagne, should present the oral argument); Brief for Respondents (M cConnell) at 50, G lickman v. Wileman B ros. \& Elliott, 117 S. Ct. 2130 (1997) (N o. 95-1184) (listing M oody as one of the submitting attorneys). 
Gerawan's position, thereby weakening their testimony that Campagne's oral argument was the cause-in-fact of the loss.

A nother option for $\mathrm{G}$ erawan is to call Supreme Court specialists to testify. Given the media statements of such specialists, ${ }^{197} \mathrm{G}$ erawan probably will be able to find Supreme Court specialists to testify that Campagne caused the adverse decision in Wileman. Campagne probably can find his own witnesses who are willing to contest the opinions; it is not a given that Supreme Court specialists are superior at oral argument. That is, for every witness who opines that Campagne's concessions caused the adverse decision, Campagne should be able to call a witness to downplay the need for specialists and to argue that Campagne was not the cause.

In addition to presenting his own specialists as expert witnesses, Campagne can point to several factors that might undermine the credibility of G erawan's specialists. For example, Supreme Court specialists have a great self-interest in promoting the importance of their trade. Campagne can emphasize to the court the self-serving nature of Supreme Court specialist testimony. A fter all, specialization occurred, in part, to help firms compete for business and expand their practices. ${ }^{198}$

Campagne can also point to the fact that the Court itself has suggested that litigants be wary of specialists. A t least two J ustices have warned litigants about the pitfalls of hiring specialists. B oth J ustice $\mathrm{O}^{\prime} \mathrm{C}$ onnor and Chief J ustice R ehnquist have expressed reservations about hiring specialists when a case reaches the Supreme Court. ${ }^{199} \mathrm{M}$ oreover, the Supreme Court has indicated that it factors the possibility of missteps at oral argument into its decisions. In M oose L odge N o. 107 v. Irvis, ${ }^{200}$ Chief J ustice R ehnquist, writing for

197. For example, B ruce Ennis, a partner at the Washington, D.C. office of Chicago's J enner \& Block who has appeared as counsel in more than 250 Supreme Court cases, stated, "[i]t's horrible to watch [non-specialists], just horrible .... People usually bring their close friends and family along to the court, only to see them get embarrassed or caught up in conundrums. It's very unpleasant." Segal, supra note 45, at F12 (internal quotation marks omitted). Expressing similar sentiments, A ndrew Frey, of Mayer, once opined: "We [Supreme Court specialists] know how to hit the right notes in a way that an ordinary practitioner wouldn't know." J oan Biskupic, L egal Elite Vie for Court Time in Pursuit of Supreme Challenge, W A SH. POST, D ec. 2, 1996, at A 19 (internal quotation marks omitted).

198. See supra notes 50-52 and accompanying text.

199. See Biskupic, supra note 197, at A 19 (recounting observations by Justice O 'Connor that hometown lawyers may do as well as or as badly as Washington-based lawyers and by Chief J ustice R ehnquist that specialists may be unfamiliar with the facts and the lower court record of a case).

200. 407 U .S. 163 (1972). 
the majority stated: "We are loathe to attach conclusive weight to the relatively spontaneous responses of counsel to equally spontaneous questioning from the Court during oral argument." ${ }^{201}$ In Rose v. $M$ itchell, ${ }^{202}$ J ustice B lackmun, writing for himself, J ustice B urger and Chief Justice Rehnquist, stated that although a "flat concession" normally would be given effect, the Court would overlook the concession if it were plainly incorrect. ${ }^{203} \mathrm{~A}$ ccordingly, Campagne can present strong evidence not only to contradict testimony that witnesses for $\mathrm{G}$ erawan might put forth, but also to demonstrate that a specialist was not necessary in light of the Court's willingness to look beyond attorney error during oral argument.

$G$ iven the existence of these countervailing arguments, it will be extremely difficult, if not impossible, for Gerawan to persuade the trial court that had Campagne's oral argument been different, Gerawan and the other respondents would have prevailed in Wileman. Therefore, Gerawan most likely will fail to prove causation and will lose the legal malpractice suit.

\section{THE RAMIFICATIONSOF FINDING FOR GERA WAN}

The history of Campagne illustrates the difficulty, if not impossibility, of proving causation with respect to an injury that allegedly occurred during oral argument. First, it is difficult to identify an issue with respect to which attorneys are not granted protection. ${ }^{204}$ Second, the probability that the alteration of one single component of an oral argument would change the outcome of a complex case is remote. Wileman was litigated thoroughly in four lower federal courts. ${ }^{205} \mathrm{O}$ ver a span of more than eight years, numerous attorneys for both the respondents and the petitioners studied the issue, as did six judges and their judicial staffs. ${ }^{206} \mathrm{~A}$ fter the Supreme Court granted certiorari in

201. Id. at 170.

202. 443 U .S. 545 (1979).

203. See id. at 573-74. Former Deputy Solicitor General Stephen M. Shapiro has interpreted I rvis and Rose to stand for the principle that, if after completion of the oral argument, an attorney realizes that she made an improvident concession on a point of major significance, it may be appropriate to send a concise letter to the J ustices through the Clerk. See Shapiro, supra note 45 , at $546 \mathrm{n} .21$. It is interesting to note that McConnell, who was at Mayer with Shapiro at the time oral argument was presented, apparently did just this. O ne day after the oral argument, McConnell sent a letter disavowing any concessions made by Campagne. See M cConnell L etter, supra note 91 , at 1.

204. See supra pp. 131-37.

205. See supra pp. 120-24.

206. See supra pp. $120-24$. 
Wileman, the Justices and their highly educated clerks researched and contemplated the issues. The Court also received input from the Solicitor $\mathrm{G}$ eneral's office, ${ }^{207}$ two attorneys for the respondents, ${ }^{208}$ and numerous other groups whose opinions were documented in amicus briefs. ${ }^{209}$ Thus, the probability that those who studied the case missed an issue or omitted a certain characterization of an issue is minimal.

However, the inability of Gerawan to prove causation directly conflicts with one of the goals behind allowing recovery for legal malpractice. Legal malpractice was instituted by the courts to: (1) provide remedies to victims of attorney negligence; (2) force negligent attorneys to bear the costs of their behavior; and (3) deter further malpractice. ${ }^{210}$ The likely outcome of Campagne directly thwarts the first goal because although G erawan can most likely prove Campagne breached the appropriate standard of care, it probably cannot recover. ${ }^{211}$

The incompatibility of a stringent causation requirement with the goal of redressing injury from attorney negligence is not limited to cases where the alleged negligence occurred during oral argument before the Supreme Court. Since all legal malpractice suits require a "trial-within-a-trial," commentators have argued that legal malpractice doctrine is flawed ${ }^{212}$ and courts should more away from the "but for" standard in all legal malpractice cases because proof of causation is too difficult. ${ }^{213}$

207. See supra pp. 120-24; see also Brief for the Petitioner, Glickman v. Wileman Bros. \& Elliott, 117 S. Ct. 2130 (1997) (N o. 95-1184), available in 1996 WL 494305 (lisiting the Solicitor $\mathrm{G}$ eneral as the counsel of record for the petitioner).

208. See supra note 99.

209. For instance, various agricultural organizations filed amicus briefs. See, e.g., Brief A mici Curiae for the National A ssociation of State D epartments of A griculture, The National M ilk Producers Federation, and the National Cattleman's B eef A ssociation, Inc. in Support of Petitioner, Wileman (No. 95-1184), available in 1996 WL 419702; B rief A mici Curiae for the Washington A pple Commission, Idaho Potato Commission, California Kiwifruit Commission, the A Imond A lliance, California Stone Fruit Coalition and A merican M ushroom Institute in Support of Petitioner, Wileman (No. 95-1184), available in 1996 WL 422143; B rief A mici Curiae for Sun-M aid Growers of California in Support of R espondents, Wileman (No. 95-1184), available in 1996 W L 554418.

210. See Tom W. Bell, Note, Limits on the Privity and A ssignment of L egal Malpractice Claims, 59 U. CHI. L. REV. 1553, 1553-54 (1992).

211. See supra Part III.

212. See Erik M. Jensen, Note, The Standard of Proof of Causation in L egal Malpractice Cases, 63 CORNELL L. REV . 666, 670 (1978) (arguing that the high causation standard, in effect, immunizes negligent attorneys from even the most reprehensible behavior).

213. See Paul G ary K erkorian, N egligent Spoliation of E vidence: Skirting the "Suit Within a Suit" Requirement of Legal Malpractice Actions, 41 HASTINGS L.J. 1077, 1083 (1990) 
O ne suggestion has been to modify the "but for" causation standard to "loss of chance," a doctrine from medical malpractice case law. "L 214 " oss of chance" is applied in medical malpractice cases when a deceased plaintiff "had a less than fifty-one percent chance of surviving to a certain date at the time the misdiagnosis occurred." ${ }^{215}$ By definition, such plaintiffs cannot establish "but for" the negligence of the physician they would have survived longer. ${ }^{216}$ Frequently, however, such plaintiffs can prove there was a chance of avoiding some adverse result. ${ }^{217}$ If a plaintiff proves there was a chance to avoid the harm, the jury is allowed to infer causation. ${ }^{218}$ A pplied to legal malpractice, the plaintiff would only need to convince a jury that the attorney's conduct diminished the chance of receiving a favorable verdict. ${ }^{219}$ This is a significantly lighter burden than that imposed by the current "but for" causation test. The loss of chance doctrine could

(discussing how commentators have expressed dissatisfaction with traditional legal malpractice and arguing for the adoption of the principle of negligent spoliation of evidence); Developments in the L aw - L awyers' Responsibilities and L awyers' Responses, 107 H A RV. L. REV . 1547, 1558 (1994) (suggesting that an alternative system should be developed to compensate legal malpractice victims because litigation is too expensive and undercompensates plaintiffs); J ensen, supra note 212 , at 681 ("A restrictive 'but for' standard of causation has rendered the 'client's remedy' no remedy at all." ); K enneth G . L upo, N ote, A M odern A pproach to the L egal Malpractice Tort, 52 IND. L.J. 689, 690-91 (1977) (arguing that in legal malpractice cases, the burden that the plaintiff must bear should be reduced).

214. See L ori R . E llis, N ote, L oss of Chance as Technique: Toeing the L ine at F ifty Percent, 72 TEx. L. REv. 369, 369-70 (1993); J ensen, supra note 212, at 679-81; Polly A . Lord, Comment, L oss of Chance in L egal Malpractice, 61 WA SH. L. REV. 1479, 1485-91 (1986). L oss of chance has been adopted in both England and France. See J ohn L eubsdorf, L egal M alpractice and Professional Responsibility, 48 RUTGERS L. REV. 101, 148-49 (1995). A Ithough some courts have interpreted Smith v. L ewis, 530 P.2d 589 (Cal. 1975), as replacing the "but for" approach with the lesser standard of "lost opportunity," see J enkins v. St. Paul Fire \& M arine Ins. Co., 422 So. 2d 1109, 1114-15 (L a. 1982) (D ennis, J ., dissenting), recently the California Court of A ppeals for the Second D istrict has repudiated this idea. See M attco Forge, Inc. v. A rthur Y oung \& Co., 52 Cal. A pp. 4th 820, 834 (Ct. A pp. 1997) ("Certainly to date, no ... approach [other than "but for"] has been accepted by the courts.").

In the alternative, California courts could adopt an approach similar to that of the O hio courts-repudiate the "but for" standard of causation but not specify the new standard. See V ahila v. H all, 674 N.E .2d 1164, 1170 (O hio 1997) ("[W ]e cannot endorse a blanket proposition that requires a plaintiff to prove, in every instance, that he or she would have been successful in the underlying matter. Such a requirement would be unjust, making any recovery virtually impossible for those who truly have a meritorious legal malpractice claim."). The only guidance provided is that the plaintiff "may be required... to provide some evidence of the merits of the underlying claim." Id.

215. See Ellis, supra note 214 , at 369.

216. See id. at 369-70.

217. See L ord, supra note 214 , at 1479 .

218. See J ensen, supra note 212 , at 680 .

219. See L ord, supra note 214 , at 1487 nn.53 \& 55 . 
provide a remedy to litigants such as $\mathrm{G}$ erawan because historical data exist that suggest a correlation between retaining a specialist and a favorable Supreme Court outcome. ${ }^{220}$

While adopting loss of chance in the legal malpractice field would, in some cases, allow recovery for litigants who might not recover under the "but for" standard of causation, it would also have some drawbacks. If $\mathrm{G}$ erawan prevails, other litigants who receive adverse decisions from the Supreme Court are likely to sue their attorneys. Given the comparatively small cost of filing and litigating a legal malpractice action, litigants may be tempted to pursue weak claims in hopes of significiant recovery.

Furthermore, the increased likelihood of facing a legal malpractice suit, combined with an established duty to associate with or professionally consult a specialist, may well make general practitioners more hesitant to take Supreme Court cases in the future. This would ultimately harm all Supreme Court litigants. As mentioned previously, the cost of retaining a specialist is already astronomical. ${ }^{221}$ If only a limited pool of attorneys are willing to brief and argue cases before the Court, their services could become too expensive for many litigants, thus restricting access to the Court.

In addition, adoption of loss of chance would, in effect, necessitate developing a system for predicting Supreme Court outcomes. ${ }^{222}$ Loss of chance would spawn a cottage industry of scholars and experts who would engage in arbitrary and unreliable statistical evalua-

220. See MCGUIRE, supra note 36 , at 191 (concluding from his statistical analysis that advocates with prior Supreme Court experience prevail more often). Correlation, of course, does not necessarily mean causation. The Solicitor G eneral, the most experienced litigator before the Court, enjoys frequent success. See supra note 59 and accompanying text. H owever, the Solicitor's success is due more to the careful process of choosing which cases merit pursuit than to his level of experience. See Robert M. Lawless \& Dylan Lager Murray, An Empirical A nalysis of Bankruptcy Certiorari, 62 M O. L. REV. 101, 112 (1997). In addition, "[u]nlike attorneys in private cases, the Solicitor General's exercise of discretion is not subject to the demands of private clients." Id. at 113.

221. See supra note 134 and accompanying text.

222. A lready, some legal scholars engage in statistical analyses of past Court decisions in an attempt to predict future decisions. See generally $L$ ynn A. Baker, Interdisciplinary D ue Diligence: The Case for Common Sense in the Search for the Swing J ustice, 70 S. CA L. L. REV . 187 (1996) (using statistical analyses of the 1994 and 1995 Terms to determine the swing voter to whom litigants should focus their arguments for the greatest impact); Paul H. E delman $\&$ Jim Chen, "D uel" Diligence: Second Thoughts A bout the Supremes as the Sultans of Swing, $70 \mathrm{~S}$. CAL. L. REV. 219 (1996) (same). 
tions. In light of these considerations, the adoption of loss of chance in the legal malpractice field would be ill-advised. ${ }^{223}$

M oreover, failing to adopt of loss of chance may not be as bad for litigants as it initially would seem. A lthough maintaining the causation status quo thwarts the first goal of legal malpractice, the unique place the U nited States Supreme Court holds in the legal system has given rise to informal protections that accomplish the other two policies underlying legal malpractice: to force negligent attorneys to bear the costs of their behavior, and to deter further malpractice. ${ }^{224}$ A ttorneys prepare assiduously because oral argument before the Court is the "Super B owl of A merican jurisprudence." ${ }^{225}$ In effect, the prestige that accompanies briefing a case and presenting the argument deters negligent behavior that could lead to malpractice suits. The media watches the Supreme Court carefully and neither the legal nor the mainstream media hesitates to publish biting critiques of attorneys who argue before the Court. In addition, when a case is granted certiorari, litigants receive volumes of unsolicited information and numerous opinions regarding the abilities of their attorneys and the pros and cons of hiring a specialist. ${ }^{226}$ These two factors combine to force attorneys to bear the cost of their behavior. N egative articles that appear following a Supreme Court performance likely would deter litigants from hiring the attorneys featured. Consequently, such attorneys would face a decline in their business. Moreover, if an attorney is known for a poor performance at oral argument, it is probable that the unsolicited information sent to Supreme Court litigants would point out such a reputation.

A Ithough the legal system can remedy perceived defects with the "but for" causation standard, any such remedy may cause significant

223. Furthermore, as a practical matter, California courts have rejected the adoption of loss of chance in the field of medical malpractice. See D umas v. Cooney, 235 Cal. A pp. 3d 1593, 1609 (Ct. A pp. 1991) (rejecting loss of chance in the context of medical malpractice, in part because of the ramifications it would have on legal malpractice).

224. See B ell, supra note 210 , at 1553-54 (listing the policies underlying legal malpractice).

225. Segal, supra note 45, at F12; see also A lexander Wohl, In the 'Bigs': Supreme Court A ppearances A re a Rare O pportunity for Small-Firm L awyers, 81 A .B.A . J ., Feb. 1995, at 46, 46 (referring to an appearance before the Supreme Court as "the World Series and the Super Bowl rolled into one").

226. For example, in O 'Gilvie v. United States, 519 U.S. 79 (1996), the lead attorney received "numerous letters from D.C. firms and the surrounding area offering to do the [oral] argument." Coyle, supra note 53, at A 1 . In these solicitations, attorneys do not hesitate to discuss why they should be retained. For example, L awrence Tribe, a recognized constitutional scholar, once wrote to an attorney, "because of my academic reputation I hold myself to a higher standard than ordinary advocates." B iskupic, supra note 197, at A 19. 
problems. Since some protection already exists for litigants, California should maintain the causation status quo.

\section{CONCLUSION}

Campagne \& A ssocs., Inc. v. G erawan Farming Inc. illustrates a problem common to all legal malpractice: causation is so difficult to prove that litigants are likely to fail. B ased on the facts of the case, Gerawan might appear wronged. A Ithough G erawan specifically retained a Supreme Court specialist, its positions were presented to the Court by an advocate whose performance the California trial court could find substandard.

Nevertheless, Gerawan loses. First, all of the issues that Gerawan identified that a specialist would have argued differently fall under the broad protections from legal malpractice granted to attorneys. Second, causation is extremely difficult to prove. This difficulty is compounded because the alleged malpractice occurred during oral argument before the Supreme Court.

A t some point the ability to litigate must stop. The question is where to draw the line. For some cases, the position of the line will be difficult to draw. H owever, the facts of Campagne brings to the fore a bright line that can be drawn: courts should not recognize a cause of action for legal malpractice when the alleged injury occurred during oral argument before the Supreme Court. 